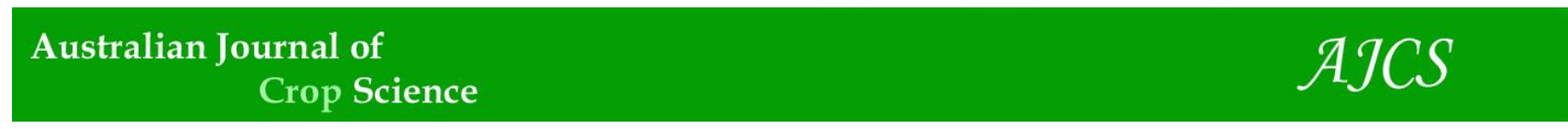

AJCS 11(03):271-276 (2017)

ISSN:1835-2707

doi: 10.21475/ajcs.17.11.03.pne360

\title{
Growth and volume of Myracroduon urundeuva Allemão after ten years of silvicultural interventions
}

\section{Ana Carolina Freitas Xavier ${ }^{1}$, Carlos de Melo e Silva-Neto*² ${ }^{2}$, Thalles Oliveira Martins ${ }^{3}$, Fernanda Gomes Ferreira $^{4}$, Marina Morais Monteiro ${ }^{4}$, Guilherme Murilo de Oliveira ${ }^{4}$, Fábio Venturoli ${ }^{4}$}

${ }^{1}$ Federal Technology University of Paraná, Londrina, Paraná, Brazil

${ }^{2}$ Federal Institute of Education, Science and Technology of Goiás (IFG), Goiás City, Goiás, Brazil

${ }^{3}$ University of Brasília, Department of Forest Engineering, Darcy Ribeiro Campus, Zip Code: 04357, Post

Code: 70904-970, Asa Norte, Brasilia/DF, Brazil

${ }^{4}$ Federal University of Goiás, Campus Samambaia, Zip Code: 74900-000; Goiânia, Goiás, Brazil

*Corresponding author: carloskoa@gmail.com

\begin{abstract}
The application of low impact silvicultural management techniques encourage the growth of tree species of high commercial value without interfering negatively in natural regeneration. The Myracroduon urundeuva has high mechanical strength, high density and considerable durability, therefore being highly used in construction, woodworking and carpentry, but had an intense and predatory exploration process devastating its natural populations due to its multiple uses The objectives of this study were to evaluate the diametrical increase of Myracroduon urundeuva Allemão adults and assess the influence of competition elimination treatments on the population structure and dynamics. A total of twelve plots of $750 \mathrm{~m}^{2}$ were established side by side. The experimental plots were randomly submitted to different treatments after the vegetation survey: (T1) - witness; $\mathrm{T}_{2}$ - removal of woody species within a onemeter radius $(1 \mathrm{~m})$ for each individual of Myracrodruon urundeuva with DBH $>9 \mathrm{~cm}$; treatment $3(\mathrm{~T} 3)-$ same as T2 plus the removal of vines throughout the plot. A total of 22 individuals were submitted to tree log scaling using the non-destructive method of Huber in October 2014. The relative gains in diameter were higher in treatment 3. Diameter increase was observed in the ten-year period, where the total for the witness treatment is $2.25 \mathrm{~cm} /$ year. The treatment $\mathrm{T}_{2}$ had a diameter growth of $0.90 \mathrm{~cm} / \mathrm{year}$ and $\mathrm{T} 3 \mathrm{of}$ $2.94 \mathrm{~cm} /$ year. The hypsometric equation has precision measurements similar to those found in the adjustments of hypsometric equations for natural forests and for isolated species. The volumetric models were of good performance highlighting the Näslund model.
\end{abstract}

Keywords: seasonal forests, increase, volume.

Abbreviation: Forest management; timber resources; Lianas competition

\section{Introduction}

Seasonal forests (SFs) are so called because their dynamics is related to climatic seasonality (Oliveira-Filho and Rattter, 2002). The SFs occur in the Cerrado by a set of disjunctions or natural fragments, which are still distributed throughout the biome and coincide with well-drained and high fertility soil areas (Eiten, 1994; Oliveira-Filho and Ratter, 2002).

The removal species without using low-impact methods in disturbed forests and forest fragments, usually leads to increased abundance of lianas, reaching levels where the selfregulation or homeostasis mechanisms of the ecosystem are not enough to prevent irreversible structural and functional degradation processes (Engel et al, 1998). In such cases, the lianas itself may not be the primary degradation causes, but may be contributing to the degradation process, and, therefore, its control has been recommended as a conservationist management tool (Engel et al., 1998; Venturoli et al., 2015).

The greatest current challenges are to reduce destructive effects of human interventions in remaining areas, to reconstruct the vegetation of deforested areas reestablishing connectivity between fragments and disjunctions and to develop sustainable methods of forest exploitation (Pereira et al., 2011). This challenge is being faced by investigations that seek to evaluate the behavior of the SFs given the application of low impact silvicultural management techniques, which are designed to encourage the growth of tree species of high commercial value without interfering negatively in natural regeneration (Venturoli et al., 2015; Silva-Neto et al., 2015).

Myracrodruon urundeuva Allemão (also known as aroeira) belongs to the Anarcadiaceae family, is usually deciduous, heliophytic and selective xerophytic (Santin and Leitão-Filho, 1991). The M. urundeuva has great geographical distribution in South America, and in Brazil it occurs in the Northeast, Southeast and Midwest regions (Dorneles et al., 2005). M. urundeuva is a species exclusive to SFs (Módena, 2010) and its wood has high mechanical strength, high density and considerable durability, therefore being highly used in construction, woodworking and carpentry (Lorenzi, 1992).

The $M$. urundeuva had an intense and predatory exploration process devastating its natural populations due to its multiple uses (e.g., timber use in the construction of posts and pens). 
In addition, the selective exploitation of the mastic tree to be used in the timber industry virtually wiped out the large individuals (Brandão, 2000). Therefore, this tree species was considered endangered and categorized as vulnerable until December 2014 (Mendonça and Lins, 2000).

In view of the above, this study aimed to evaluate the growth of $M$. urundeuva submitted to three silvicultural treatments which consisted of competition release and liana cutting operations to increase the diameter of individuals of the species.

\section{Results and discussion}

\section{Ten-year growth}

Treatment 3 (T3 - removal of woody species in a distance of one meter from each Myracrodruon urundeuva Allemão individual with $\mathrm{DBH}>9 \mathrm{~cm}$ plus the removal of lianas) differed from treatment 2 (T2 - removal of woody species in a distance of one meter from each mastic tree individual with $\mathrm{DBH}>9 \mathrm{~cm}$ ), and was higher than T2 and T1. Diameter increases were greater for treatment 3 . Treatment 1 provided lesser growth than treatment 3 in $23.61 \%$. Treatment 2 was lower than the other treatments. Only treatment 3 (T3 removal of woody species in a distance of one meter from each Myracrodruon urundeuva individual with DBH $>9 \mathrm{~cm}$ plus the removal of lianas) differed from the other treatments. $M$. urundeuva individuals present in the treatment where woody species were removed in a distance of one meter from each $M$. urundeuva individual with DBH $>9 \mathrm{~cm}$ plus the removal of large lianas in all of the plot had a more prominent growth.

The lianas are frequently considered a nuisance and its removal prior to wood exploitation is recommended as a component of a reduced impact management (Barreto et al., 1998). Liana cutting has been evaluated as a silvicultural treatment to increase tree growth, by reducing population density and, consequently, local competition (Gerwing and Vidal, 2003; Gerwing, 2006). Such inference is based on the strong influence that light has on tree growth, natural regeneration (Silva et al., 1995; Gerhardt, 1996; Pariona et al., 2003), and on the colonization by native species (D'antonio and Vitousek, 1992). A certain amount of canopy openness is necessary in secondary forests for the growth and regeneration of the desired trees hindering the establishment of undesired and/or invasive species that may interfere negatively on natural regeneration (Freitas, 2004). The effects of lianas on individual trees may be perceived by their growth and mortality rates. The lianas compete with tree for light and space, and for water and nutrients and for space for leaf development (Stevens, 1987; Clark and Clark, 1990). In addition, lianas cause physical injuries due to its weight and on the canopies and the effects in torque caused by winds (Putz, 1991). Therefore, the expected effects of lianas are usually negative and must truly be considered in timber production forests.

The proportion of trees infested by lianas in a forest may indicate the potential of lianas killing their hosts. About 43 to $47 \%$ of the trees with more than $20 \mathrm{~cm} \mathrm{DBH}$ at Barro Colorado, Panamá are infested by lianas (Putz, 1984), as are $50 \%$ of the trees of a forest at Sarawak, Malásia (Putz and Chai, 1987). On average $69.3 \%$ of the trees with $\mathrm{DBH}>10$ $\mathrm{cm}$ are colonized by lianas on the canopy or trunk in a $60 \mathrm{ha}$ fragment of a late secondary forest in Botucatu, SP. The load of lianas is positively related with the diameter of the tree host (Clark and Clark, 1990). It is common to find trees infested by more than one liana showing that some trees are more susceptible to infestation, or that colonization by a liana facilitates the appearance of others (Engler et al. 1998; SilvaNeto et al., 2015; Venturoli et al., 2015).

\section{Diameter increase}

The total diameter increase for the ten year period for the witness treatment amounted to $2.250 \mathrm{~cm} /$ year, for T2 to 0.906 $\mathrm{cm} /$ year and T3 to $2.945 \mathrm{~cm} /$ year. The medial growth in ten years was $0.120 \mathrm{~cm} /$ year (T1), $0.088 \mathrm{~cm} /$ year (T2) and $0.1371 \mathrm{~cm} /$ year (T3), as shown in figure Figure 2 .

Differences in the increases in the diameter of the individuals between the witness (treatment 1 ) and the other treatments $(2$ and 3$)(\mathrm{p}<005)$ were observed in 2003. The results found for the M. urundeuva Allemão population in the Semideciduous seasonal secondary forest studied showed that the individuals of this species responded positively to the silvicultural interventions, once the largest increases in diameter were observed in the plots where the only intervention was the removal of lianas. These results supported the classical theory of diametrical growth related directly with spacing between trees in the forest (Oedekoven, 1968; Smith, 1986). A study carried out with the community of the same area found that the annual medial increases in diameter of the species, in the plots submitted to silvicultural treatments, followed the intensity of interventions, being higher in the treatments with more intense intervention (treatments 2 and 3) (Venturoli et al., 2015).

The treatment consisting of freeing the desirable individuals (treatment 2 ) had a median $(0.27 \mathrm{~cm} /$ year $) 6 \%$ higher than the witness (treatment 1), which had the lowest medial diameter increase among treatments $(0.26 \mathrm{~cm} / \mathrm{year})$. The treatment consisting of freeing the desirable individuals (treatment 3) plus liana removal had a median $15 \%$ higher than the witness, reaching $0.30 \mathrm{~cm} /$ year. The growth in medial diameter in the community was $0.28 \mathrm{~cm} /$ year (for a four-year period - 2003 to 2007) and the medial diameter increase for $M$. urundeuva Allemão (for a ten-year period 2003 to 2013) recorded in this study was $0.13 \mathrm{~cm}^{\text {.year- }}{ }^{1}$.

M. urundeuva Allemão interacted with the other species of the seasonal forest, so the removal of woody species on a $1.0 \mathrm{~m}$ radius surrounding each individual significantly affected the diametrical growth. The concentration of individuals in the lower diameter classes suggested that the trees are small, as is typically found in secondary forests (see Figure 3).

Uneven-aged forest stands (with individuals in different developmental stages) tend to have a higher number of individual in the lower diameter classes due to the natural forest succession under the competition dynamics, as many individuals die and recruitment is faster when few reach adulthood, maintaining forest balance. In higher diameter classes, few individuals represented the diameter increase, and may have not represented the behavior of the population due to the small number of replicas (only two individuals), thus explaining the removal of individuals considered outliers in the hypsometric model and later allometric equations.

\section{Hypsometric relation}

The adjusted hypsometric relation adjusted for the values of $2003\left(\mathrm{Y}=0.01688(\mathrm{DBH})^{3}-0.2483(\mathrm{DBH})^{2}+1.824(\mathrm{DBH})\right.$ +0.9683 ), with the parameters $\beta_{0}=0.968251, \beta_{1}=1.82383$, $\beta_{2}=-0.248284, \quad \beta_{3}=0.0168817$ and a coefficient of determination of 0.78594 . This equation was used to estimate 
Table 1. Parameter estimations and measures of the accuracy of the equations in estimating the stock in volume of trees Myracrodruon urundeuva Allemão with DBH $>9 \mathrm{~cm}$, in a Semideciduous seasonal secondary forest, in Pirenópolis GO, in $2013\left(\beta_{0}\right.$, $\beta_{1}, \beta_{2}$ and $\beta_{3}$ - parameters of models; $R^{2}$ - Regression coefficient ; $S_{\mathrm{yx}}-$ Standard error).

\begin{tabular}{|c|c|c|c|c|c|c|}
\hline & $\beta_{0}$ & $\beta_{1}$ & $\beta_{2}$ & $\beta_{3}$ & $\mathrm{R}^{2}$ & Syx \\
\hline $\begin{array}{l}\text { Näslund: } Y=\beta_{0} \mathrm{DBH}^{2}+\beta_{1} \mathrm{DBH}^{2} \mathrm{H}+ \\
\beta_{2} \mathrm{DBH}^{*} \mathrm{H}^{2}+\beta_{3} \mathrm{H}^{2}\end{array}$ & -0.0096 & 0.0202 & -0.0002 & 0.0000006 & 0.9844 & 0.0166 \\
\hline Ogaya: $Y=\mathrm{DBH}^{2}\left(\beta_{0}+\beta_{1} \mathrm{H}\right)$ & -0.0041 & 0.0181 & ---- & ---- & 0.9841 & 0.0172 \\
\hline Schumacher and Hall: $Y=\beta_{0} \mathrm{DBH}^{\beta 1} \mathrm{H}^{\beta 2}$ & -0.0095 & 0.0202 & -0.0002 & ---- & 0.9843 & 0.0189 \\
\hline Logarithmic Spurr : $Y=\beta_{0}\left(\mathrm{DBH}^{2} \mathrm{H}\right)^{\beta 1}$ & -0.0667 & 0.0989 & ---- & ---- & 0.9627 & 0.0201 \\
\hline Honner: $\mathrm{Y}=\mathrm{DBH}^{2} /\left(\beta_{0}+\beta_{1} \mathrm{H}\right)$ & 0.0314 & 0.1894 & ---- & --- & 0.9323 & 0.0187 \\
\hline Takata: $\mathrm{Y}=\left(\mathrm{DBH}^{2} \mathrm{H}\right) /\left(\beta_{0}+\beta_{1} \mathrm{DBH}\right)$ & 0.0155 & 1.0641 & ---- & ---- & 0.9578 & 0.0181 \\
\hline Husch: $Y=\beta_{0} \mathrm{DBH}^{\beta 1}$ & 0.0155 & 1.0641 & ---- & ---- & 0.9678 & 0.0191 \\
\hline
\end{tabular}

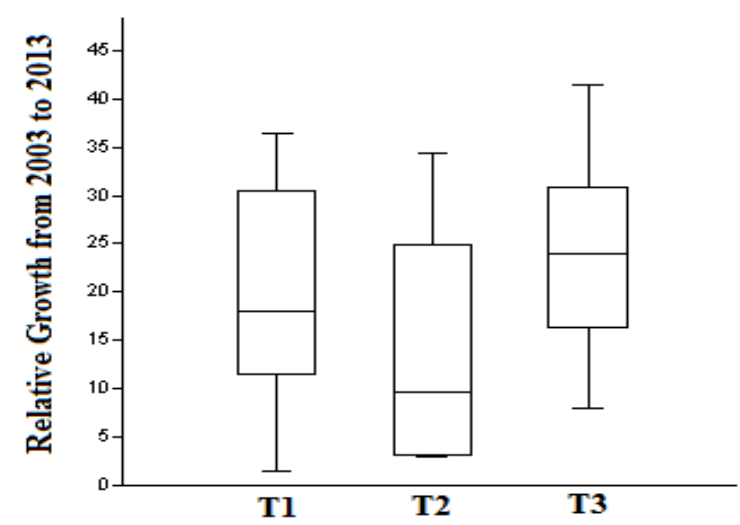

Fig 1. Box plot comparing medians between treatments and the relative 10-year growth patterns (\%), among years of evaluation (mean value 2003 - 2013 - T1 - witness; $\mathrm{T}_{2}$ - removal of woody species within a one-meter radius (1 m) for each individual of $M$. urundeuva with $\mathrm{DBH}>9 \mathrm{~cm}$; T3 - same as T2 plus the removal of vines throughout the plot).

the height of the individuals in 2013. The adjusted hypsometric equation in this study shows similar accuracy measurements to those found in hypsometric equations adjusted for natural forests and exotic species. Andrade et al. (2006) adjusted hypsometric equations for a fragment of Seasonal Semidecidous forest in the northern region of the state of Rio de Janeiro and found a coefficient of determination between 0.61 and 0.85 , similar to the values recorded in this study. Tonini and Schwenberg (2006), tested eight hypsometric models for Acacia mangium crops in Roraima, and obtained $\mathrm{R}^{2}$ between 0.41 and 0.98 . Tonini et al. (2008) evaluated six hypsometric models for native Brazil nut tree populations (Berthollettia excelsa Bonpl.) and found $\mathrm{R}^{2}$ between 0.54 and 0.70 , lower than the recorded in this study.

The best hypsometric model for estimating total height (Ht) of $M$. urundeuva in an area classified as Seasonal semideciduous Montana forest in the Atlantic Forest Domain, was an exponential model with a coefficient of determination of $68.64 \%$ (lower than the recorded in this study), standard deviation of $2.17, \beta_{0}=3.613484$ and $\beta_{1}=0.542622$ (Soares et al. 2011). Comparisons with other studies show that the hypsometric equation obtained for $M$. urundeuva in a Semideciduous seasonal secondary forest in Pirenópolis, Goiás has an intermediate to good classification.

\section{Volumetric models}

All the equations were highly significant, with high $\mathrm{F}$ values, $\mathrm{p}<0.05$, high coefficients of determination $\left(\mathrm{R}^{2}\right)$ and low error estimations (Syx) (see figure 9 for the residue distribution). Some models had different behaviours as regards residue distribution despite the models being highly significant. The dada are not ideally distributed in some models with sinous distributions, which may be due to the small number of repetitions.

The values found for the mastic tree were 0.442405 . Negative signals of the coefficients associated with the total height $(\mathrm{Ht})$ indicate an error in estimating these coefficients, once $\mathrm{Ht}$ is alwas positivelly correlated with bark volume. Therefore, the Schumacher and Hall models were not chosen for exhibiting inconsistency in the coefficient associated with $\mathrm{Ht}$, despite 


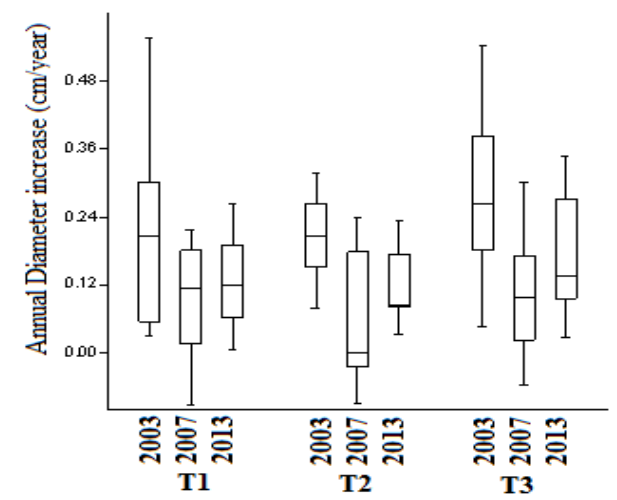

Fig 2. Box-plot comparing medians of the treatments in the ten years assessing the annual diameter increases in $\mathrm{cm} / \mathrm{year}(\mathrm{T} 1-$ witness; $\mathrm{T}_{2}$ - removal of woody species within a one-meter radius $(1 \mathrm{~m})$ for each individual of $M$. urundeuva with DBH $>9 \mathrm{~cm}$; T3 same as $\mathrm{T} 2$ plus the removal of vines throughout the plot)

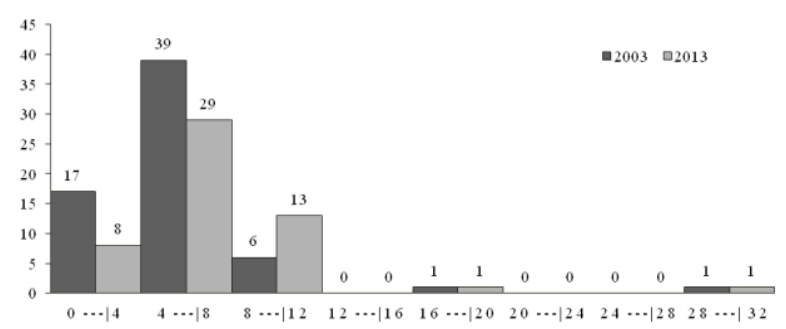

Fig 3. Distribution of absolute frequencies among diameter classes (show in centimeters) for Myracrodruon urundeuva Allemão populations.

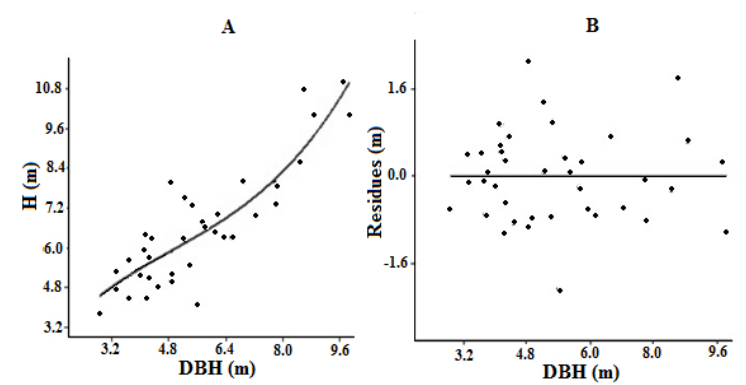

Fig 4. Representation of the $3^{\text {rd }}$ order polynomial adjustment curve of the hypsometric relation $\left(\mathrm{Y}=0.01688(\mathrm{DBH})^{3}-\right.$ $\left.0.2483(\mathrm{DBH})^{2}+1.824(\mathrm{DBH})+0.9683\right)$, with the parameters $\beta_{0}=0.968251, \beta_{1}=1.82383, \beta_{2}=-0.248284, \beta_{3}=0.0168817, R^{2}=0.78594$. Graph B shows the distribution of residues of the hypsometric equation for $M$. urudeuva Allemão in a Semideciduous seasonal secondary forest, Pirenópolis - Goiás.
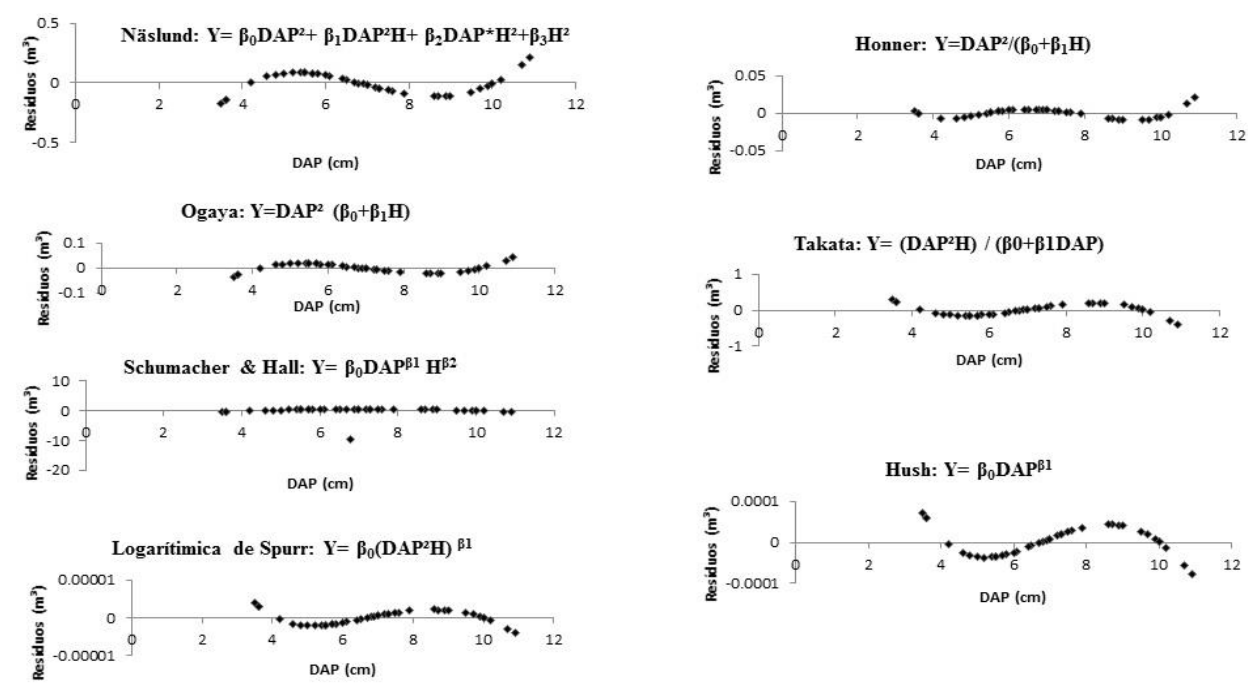

Fig 5. Residues of the volume equations for the population of M. urundeuva at the RPPN Vagafogo in a Semideciduous seasonal secondary forest. 
having the best accuracy mesures in estimating the volume of the mastic tree. The Näslund model had the best accuray measure in Cerrado sensu stricto areas when comparred to the other equations. However, the model has tendencies of overestimating the volume of smaller trees. Non-linear equations of Schumacher and Hall and Logarithmic Spurr have such a tendency (Rezende et al., 2006). Baima et al. (2001) expalined the better adjustment of the dual input equations by the fact that diameter and heigth are highly correlated with volume. The dual input equations developed for a dry land forest in Moju, PA, estimated a better volume than others. Silva et al. (1984) assigned the better adjustment for the Tapajós National Forest to the Schumacher and Hall equation.

In addition, Soares et al. (2011) reported negative coefficients associated with total height $(\mathrm{Ht})$ for the mastic trees in the respective equations. Using models that use the DBH $(\mathrm{cm})$ and $\mathrm{H}$ (total or commercial) to estimate volume are more recommended by this study for presenting a better adjustment. Using these models is also recommended for native species given that some may be managed on a sustainable approach.

\section{Materials and Methods}

\section{Study area}

The study was carried out in a fragment of Semideciduous seasonal secondary forest (Ibge, 2004), under Litholic Neosol (Ibge, 2001), located in the Wildlife Sanctuary Vagafogo in Pirenópolis, Goiás (-15 51'09" and $\left.-48^{\circ} 57^{\prime} 33^{\prime \prime}\right)$, at an average altitude of 770 meters above sea level.

\section{Experimental design}

The experiment was conducted in a randomized block design with two treatments and control. The treatments consisted on the release of competition in a distance of one meter for each Myracrodruon urundeuva Allemão individual with $\mathrm{DBH} \geq$ $9 \mathrm{~cm}$ (T2). This treatment (T2) was associated with the removal of lianas in the entire plot (T3). In addition, one of the treatments was a witness treatment, referred to treatment 1 (T1).

The blocks were defined by an environmental gradient of humidity:

- Block I - closest to the forest under the influence of Grota da Mina Stream ( \pm 60 meters), environment most influenced by the riparian environment.

- Block II - far from the Grota da Mina stream ( \pm 90 meters), environment under less influence of the riparian environment than block I.

- Block III - lesser influence of the riparin environment, largest distance from the stream and closest to the Cerrado sensu stricto.

\section{Log scaling}

M. urundeuva Allemão individuals located in the forest were scalled using the Hubber method (Soares et al., 2006), with the tree standing. The commercial height was measured using an electronic inclinometer and the diameter at breast height $(\mathrm{DBH})$ using the measuring tape. Diameter measures made for the log scaling were taken at the base of the tree trunk, at $0.30 \mathrm{~m}, 0.70 \mathrm{~m}, 1.30 \mathrm{~m}(\mathrm{DBH}), 1.60 \mathrm{~m}$ and at $1.80 \mathrm{~m}$ relative to ground level.

\section{Volumetric models}

Seven volumetric models were adjusted with the $\mathrm{DBH}$ (measured at $1.30 \mathrm{~m})\left(\mathrm{X}_{1}\right)$, in centimeters, and tree height $\left(\mathrm{X}_{2}\right)$, in meters as independent variables and the total volume and the volume of the trunk with the bark as the dependent variables as models Lemos-Junior et al. (2016). The volumetric variables used are described below:

- Näslund: $Y=\beta_{0} X_{1}^{2}+\beta_{1} X_{1}^{2} X_{2}+\beta_{2} X_{1} X_{2}^{2}+\beta_{3} X_{2}^{2}$;

- Ogaya: $Y=X_{1}^{2}\left(\beta_{0}+\beta_{1} X_{2}\right)$;

- Schumacher and Hall: $Y=\beta_{0} X_{1} \beta_{1} X_{2} \beta_{2}$;

- Logarithmic Spurr : $Y=\beta_{0}\left(X_{1}^{2} X_{2}\right) \beta_{1}$;

- Honner: $Y=X_{1}^{2} /\left(\beta_{0}+\beta_{1} X_{2}\right)$;

- Takata: $Y=\left(X_{1}^{2} X_{2}\right) /\left(\beta_{0}+\beta_{1} X_{1}\right)$;

- Husch: $Y=\beta_{0} X_{1} \beta_{1}$.

Where:

$\mathrm{X}_{1}=$ Diameter at breast height $(\mathrm{cm})$;

$\mathrm{X}_{2}=$ Height $(\mathrm{m})$;

$\beta_{0}=$ Predicted value for the height when the diameter is zero ; $\beta_{1}=$ slope of the line corresponding to the value of the first derivative;

$\beta_{2}=$ Rate of change in volume $\left(\mathrm{m}^{3}\right)$ as it occurs variation in height $(\mathrm{m})$, with constant $\mathrm{DBH}(\mathrm{cm})$;

$\beta_{3}=$ coefficient of the multivariate model;

The model selection criteria are based on the adjusted determination coefficient, the corrected residual standard and percentage error and graphical analysis of residuals.

\section{Statistical analysis}

The Kruskal-Wallis test (95\% statistical significance) was carried out to compare the diametric growth of M. urundeuva Allemão among treatments. The Kruskal-Wallis test the nonparametric test used to compare three or more independent samples. It tells us if there is a difference between at least two of the treatments and does not require normal distribution. Therefore, there was no need for normality test.

\section{Conclusion}

A better development was recorded in regards to diameter increase and relative growth for individuals of this population, submitted to more intense silvicultural interventions (treatment 3). The hypsometric equation ( $\mathrm{Y}=$ $\left.0.01688(\mathrm{DBH})^{3}-0.2483(\mathrm{DBH})^{2}+1.824(\mathrm{DBH})+0.9683\right)$ was considered satisfactory for native species of seasonal semidecidous forests. All equations were highly significant, with high values of $F, p<0.05$, high coefficients of determination $\left(\mathrm{R}^{2}\right)$ and low error estimations (Syx). Despite the models being highly significant, some models exhibited different behaviors in regards to residue distribution. Some models had sinuous distributions which may occur due to a low number of repetitions.

\section{Acknowledgements}

The authors are grateful to the members of the Forest Inventory Laboratory (in Portuguese Laif) of the Federal University of Goiás, to Evandro and Catarina for the provision of the work in the Vagafogo Private Natural Heritage Reserve (RPPN).

\section{References}

Andrade VCL, Martins SV, Calegario N, Chichorro JF (2006) Influência de três sistemas de amostragem na 
estimativa da relação hipsométrica e do volume de árvores em um fragmento de Mata Atlântica. Scie. For. 70: 31-37.

Berg MEVD, Silva MHL (1986) Contribuição ao conhecimento da flora medicinal do Maranhão. In: Simpósio Do Trópico Úmido, 1, 1984, Belém. Anais. Brasília: EMBRAPA, 11: 119-125.

Baima AV, Silva SMS, Silva JNM (2001) Equações de volume para floresta tropical de terra firme em Moju, PA. In: Silva JNM, Carvalho JOP, Yared JAG. (eds). A Silvicultura na Amazônia Oriental: contribuições do projeto silvicultura tropical (Embrapa/DFID). Embrapa Amazônia Oriental, Belém. 2:367-392.

Brandão M (2000) Caatinga. In: Mendonça MP, Lins LV (Orgs). Lista vermelha das espécies ameaçadas de extinção da flora de Minas Gerais. Belo Horizonte: Fundação Biodiversitas e Fundação Zôo-Botânica de Belo Horizonte, 75-85.

Clark DB, Clark DA (1990) Distribution and effects on tree growth of lianas and woody hemiepiphytes in a Costa Rican Tropical Wet Forest. J. Trop. Ecol. 6: 321-331.

Dorneles MC, Ranal M, Santana DG (2005) Germinação de diásporos recém colhidos de Myracrodruon Allemão (Anarcadiaceae) ocorrente no cerrado do Brasil Central. R. Bras. Bot.28 (2): 399-408.

Eiten G (1994) Vegetação do cerrado. Cerrado: caracterização, ocupação e perspectivas. 2: 17-73.

Engel VL, Fonseca RC, Oliveira RE (1998) Ecologia de cipós e o manejo de fragmentos florestais. Série técnica IPEF 12(32): 43-64.

Ibge - Instituto Brasileiro de Geografia e Estatística. Instituto Brasileiro de Geografia e Estatística. Mapa de solos do Brasil. Rio de Janeiro: 2001. Escala 1: 5.000.000.

Ibge - Instituto Brasileiro de Geografia e Estatística. Mapa de vegetação do Brasil. Rio de Janeiro: 2004. Escala 1:5.000.000.

Lan G, Zhu H, Cao M, Yuehua H, Wang H, Deng X, Zhou S, Cui J, Huang J, He Y, Liu L, Xu HE, Song J (2009) Spatial dispersion patterns of trees in a tropical rainforest in Xishuangbanna, southwest China. Ecol. Rest. 24: 11171124.

Lemos-Junior JM, Souza KR, Guimaraes LE, Oliveira FD, Monteiro MM, Goncalves RA, Silva-Neto CM, Lima NL, Venturoli F Calil FN (2016) Volumetric models for Eucalyptus grandis $\mathrm{x}$ urophylla in a crop-livestock-forest integration (CLFI) system in the Brazilian cerrado. African J. Agricul. Res. 11: 1336-1343.

Li L, Huang Z, Ye W, Cao H, Wei S, Wang Z, Lian J, Sun IF, Ma KE, He F (2009) Spatial distributions of tree species in a subtropical forest of China. Oikos 118: 495-502.

Lorenzi H (1992) Árvores brasileiras: manual de identificação e cultivo de plantas arbóreas nativas do Brasil. Ed. Plantarum, Nova Odessa.

Melo JT (1991). Aroeira-do-sertão: característica e aspectos silviculturais. Planaltina: Embrapa CPAC, Brasília, Documentos 38.

Mendonça MP, Lins LV (2000) Lista vermelha das espécies ameaçadas de extinção da flora de Minas Gerais. Belo Horizonte: Fundação Biodiversitas, 157p.

Mma - Ministério do Meio Ambiente. 2008. Lista oficial das espécies da flora brasileira ameaçadas de extinção. Instrução normativa $\mathrm{n}^{\circ} 06$, de 23 de setembro de 2008.

Módena ES (2010) Aspectos demográficos e padrão espacial de Myracrodruon urundeva M. Allemão (Anacardiaceae) na Floresta Estacional Semidecidual no domínio do Cerrado. 158 f.Tese (Doutorado em Ecologia e Conservação) - Universidade Federal do Mato Grosso do Sul, Campo Grande, MS.
Oedekoven KH (1968) Ordenamento florestal. Curitiba, 1968. FAO. $114 \mathrm{p}$.

Oliveira-Filho AT, Ratter JA (2002) Vegetation physiognomies and woody flora of the Cerrado Biome. In: Oliveira PS, Marquis RJ eds. The Cerrados of Brazil: Ecology and Natural History of a Neotropical Savanna. New York, Columbia University. 91-120.

Pereira BA, Venturoli F, Carvalho FA (2011) Florestas estacionais no cerrado: uma visão geral. Pesq. Agrop. Trop. 41 (3): 446-455.

Putz FE (1983) Liana biomass and leaf area of a tierrafirme forest in the Rio Negro Basin, Venezuela. Biotrop. 15: 185-189.

Putz FE (1991) Silvicultural effects of lianas. In: Putez FE, Mooney HA, ed. The biology of vines. Cambridge: Cambridge University Press, 493-501.

Putz FE, Chai P (1987) Ecological studies of lianas in Lambir National Park, Sarawak, Malaysia. J. Eco 75: 523-531.

Santin DA, Leitão-Filho HF (1991) Restabelecimento e revisão taxonômica do gênero Myracrodruon Freire Allemão (Anacardiaceae). R. Bras. Bot. 14 (2): 133-145.

Scolforo JRS (1998) Biometria florestal: medição e volumetria de árvores. Lavras: UFLA/FAEPE. 310p.

Scolforo JRS, Mello JM, Oliveira-Filho AT (1996) Modelo de produção para floresta nativa como base para manejo sustentado. Cerne 2 (1): 112-137.

Silva LBX, Reichmann-Neto F, Tomaselli I (1983) Estudo comparativo da produção de biomassa para energia entre 23 espécies florestais. In: CONGRESSO FLORESTAL BRASILEIRO, 4, 1982, Belo Horizonte. Anais. São Paulo: Sociedade Brasileira de Silvicultura,872-878.

Silva-Luz CL, Pirani JR (2014) Anacardiaceae in Lista de Espécies da Flora do Brasil. Jardim Botânico do Rio de Janeiro. Disponível em: <http://www.floradobrasil.jbrj.gov.br/jabot/floradobrasil/F B4394>. Acesso em: 19 Dez. 2014.

Silva-Neto CM, Venturoli F, Gonçalves Bb, Ferreira GA (2015) Incremento Diamétrico de Protium heptaphyllum (Aubl.) Marchand em Floresta estacionaL semidecídua sob manejo, em Pirenópolis, Goiás. Interc. 40: 564-569.

Smith DM (1986) The practice of silviculture. Wiley \& Sons, Inc. USA. 527 p.

Soares CPB, Martins FB, Leite-Junior HU, Silva GFD, Figueiredo LTMD (2011) Equações hipsométricas, volumétricas e de taper para onze espécies nativas. R. Árv. 35 (5): 1039-1051.

Soares TS, Leite HG, Vale AB (2004) Um modelo alternativo para a quantificação de multiprodutos em árvores individuais. R. Árv. 28 (6): 875-882.

Spurr SH (1952) Forest inventory. New York: The Ronald Press. 476p.

Iucn. The IUCN Red List of Threatened Species. Version 2013. Disponível em: 〈www.iucnredlist.org〉. Acesso em 16 de dezembro de 2014.

Tonini H, Costa P, Kaminski PE (2008) Estrutura e produção de duas populações nativas de Castanheira-do-Brasil (Berthollettia excelsa O. Berg) em Roraima. Florest. 38 (3).

Tonini H, Schwengber LAM (2006) Equações hipsométricas e volumétricas para Acacia mangium Willd em Roraima. Ambiên. 2 (2): 155-165.

Venturoli F, Carvalho FA, Silva-Neto CM, Martins TO, Moraes DC, Souza DM (2015) Manejo Florestal no bioma Cerrado: uma opção para conservar e lucrar. Scien. For. 43. 